\title{
MORPHOLOGICAL AND BIOCHEMICAL INDICES OF PIGLETS' BLOOD UNDER THE ACTION OF FEED ADDITIVE "BUTASELMEVIT-PLUS"
}

\author{
T. V. Martyshuk', B. V. Gutyj ${ }^{2}$, O. I. Vishchur ${ }^{1}$ \\ bvh@ukr.net
}

\author{
${ }^{1}$ Institute of Animal Biology NAAS, \\ 38 V. Stus str., Lviv 79034, Ukraine \\ ${ }^{2}$ Lviv National University of Veterinary Medicine \\ and Biotechnologies named after S. Gzhytsky, \\ 50 Pekarska str., Lviv 79010, Ukraine
}

The level of protective power in pigs depends on the influence of environmental factors and is reflected by the change in hematological indices of the blood, which in turn affect the intensity of metabolic and redox processes. The purpose of the search was to study the influence of feed additive "Butaselmevit-plus" on the morphological indices of the blood and the protein synthesis function of piglets' liver during weaning. The experiments were conducted on the basis of "Koshet" LLC, Mukachevo district, Transcarpathian region. Two groups of pigs were formed - control $(C)$ and experimental (E), in the number of 10 individuals in each group, selected on the basis of analogues - age, breed and body weight. In the suckling period, piglets were kept under sows in special machines, had constant access to the mother, and from 5 days of age - free access to concentrated feed. Feeding of animals was carried out according to the norms for this age of pigs. Clinical and physiological examinations of piglets were conducted prior to the search. They took into account their general condition and activity when eating feed. On the $28^{\text {th }}$ day of life, piglets were weaned and rearranged from different nests for further retention during the fattening period and growing up with the changing structure of the diet, which served as technological stress for the animal organism. Beginning from 5 days of age, piglets of all groups were fed pre-stern compound feed. The piglets of the experimental group, from 21 to 40 days of age, were additionally fed the compound feed additive "Butaselmevit-plus" at a dose of $100 \mathrm{mg} / \mathrm{kg}$ of body weight per day. Weaning of piglets from sows at 28 days of age leads to a decrease in the number of leukocytes by the $30^{\text {th }}$ day of life with a further increase by the $35^{\text {th }}$ and $40^{\text {th }}$ day of life. The use of the feed additive "Butaselmevitplus" contributed to the probable increase of hemoglobin and erythrocytes level in the blood of weaned piglets of the experimental group for the $35^{\text {th }}$ and $40^{\text {th }}$ days of the experiment. Feeding of piglets with feed additives "Butaselmevitplus" promotes enhancement of protein synthesis of liver function. Increase in content of the total protein in the serum of piglets blood from the experimental group during the specified periods of the experiment, compared with controls, indicates the stimulating influence of vitamins $A, D_{3}, E$ and milk thistle spotted in the content of the feed additive on protein synthesis. Also in the piglets'blood of the control and experimental group after weaning on the 30, 35 and 40 days of the experiment was recorded a higher content of albumin and a lower content of globulins.

Keywords: PIGLETS, BLOOD, TOTAL PROTEIN, ALBUMINS, GLOBULINS, FEED ADDITIVE "BUTASELMEVIT-PLUS”

\section{МОРФОЛОГІЧНІ ТА БІОХІМІЧНІ ПОКАЗНИКИ КРОВІ ПОРОСЯТ ЗА ДІЇ КОРМОВОЇ ДОБАВКИ «БУТАСЕЛМЕВІТ-ПЛЮС»}

\author{
T. В. Мартишук ${ }^{1}$, Б. В. Гутийㄹ, О. I. Вімурр \\ bvh@ukr.net
}

${ }^{1}$ Інститут біології тварин НААН, вул. Стуса, 38, Львів, Україна

${ }^{2}$ Львівський національний університет ветеринарної медицини та біотехнологій імені С. 3. Гжицького, вул. Пекарська, 50, Львів 79010, Україна

Рівень захисних сил у організмі свиней залежсть від впливу факторів зовнішнього середовища і відображається зміною гематологічних показників крові, які, у свою чергу, позначаються на інтенсивності обмінних та окисно-відновних процесів. Метою роботи було вивчити вплив кормової добавки «Бутаселмевіт 
плюс» на морфологічні показники крові та протеїнсинтезувальну функцію печінки поросят при відлученні. Досліди проводились на базі ТОВ «Кочет» Мукачівського р-ну Закарпатської обл. Було сформовано дві групи поросят - контрольну (К) і дослідну (Д) по 10 особин у кожній групі, підібраних за принципом аналогів - за віком, породою і масою тіла. У підсисний період поросята утримувалися під свиноматкою у спеціальних станках, мали постійний доступ до матері, а з 5-добового віку 一 вільний доступ до концентрованих кормів. Годівлю тварин проводили відповідно до норм для свиней изього віку. Перед проведенням досліджень здійснювали клінічно-фізіологічне обстеження поголів'я поросят. Враховували їх загальний стан та активність при поїданні корму. На 28-у добу жстття поросят відлучали від свиноматки та перегруповували з різних гнізд для подальшого утримання у період відгодівлі та дорощування зі зміною структури ращіону, шцо слугувало технологічним стресом для організму тварин. 3 5-добового віку поросят усіх груп підгодовували престартерним комбікормом. Поросятам дослідної групи з 21- до 40-добового віку додатково згодовували кормову добавку «Бутаселмевіт-плюс» у дозі 100 мг/кг маси тіла на добу. Відлучення поросят від свиноматок у 28-добовому віизі призводить до зниження кількості лейкоцчтів на 30-ту добу життя з подальшим підвищенням на 35i 40-у добу життя. Застосування кормової добавки «Бутаселмевіт-плюс» сприяло вірогідному збільшенню рівня гемоглобіну та еритроцитів у крові відлучених поросят дослідної групи на 35- і 40-у добу досліду. Згодовування поросятам кормової добавки «Бутаселмевіт-плюс» сприяє посиленню протеїнсинтезувальної функції печінки. Збільшення вмісту загального протеїну у сироватиі крові поросят дослідної групи у вказані періоди досліду, порівняно з контролем, вказує на стимулювальний вплив вітамінів $A, D_{3}$, Е та розторопші плямистої у складі кормової добавки на синтез протеїну. Також у крові поросят контрольної та дослідної групи після відлучення на 30-, 35- і 40-у доби досліду зафіксовано більший вміст альбумінів і менший вміст глобулінів.

\section{Ключові слова: ПОРОСЯТА, КРОВ, ЗАГАЛЬНИЙ ПРОТЕЇН, АЛЬБУМІНИ, ГЛОБУЛІНИ, КОРМОВА ДОБАВКА «БУТАСЕЛМЕВІТ ПЛЮС»}

Animal husbandry is the main branch of the agro-industrial complex, which produces most of the food of animal origin. The main purpose of this branch is to provide the population of Ukraine with sufficient high quality and environmentally clean products of animal origin that would satisfy the human organism with all the necessary substances. Reproduction of pigs plays an important role in the development of animal husbandry $[2,6,9,10]$.

According to reports in the literature, in intensive sow management, it is known that early weaning of piglets from sows is an extreme irritant, which helps to reduce the protective and adaptive reactions of piglets $[1,3]$. As a result, a stressful condition arises, accompanied by stunted growth, violation of reproductive capacity, and reducing the quality of meat products.

It is also important to note that the development of oxidative stress in piglets is accompanied by the activation of free radical oxidation of the lipids of plasma and intracellular membranes of hepatocytes against the depletion of protective antiradical systems. Activation of lipid peroxidation processes and the formation of a large number of free radicals not only causes damage to hepatocytes, as well as changes in blood cells - the most mobile system of the organism $[4,7,8]$.
That is why the purpose of the work was to study the influence of the feed additive "Butaselmevit-plus" on morphological indices of blood and protein synthesizing function of liver of piglets during weaning.

\section{Materials and methods}

The experiments were performed on the basis of LLC "Koshet", Mukachevo district, Transcarpathian region. Two groups of pigs - control (C) and experimental (E) were formed in the number of 10 individuals in each group, selected on the basis of analogues - age, breed and body weight. In the suckling period, pigs were kept under sows in special machines, had constant access to the mother, and from 5 days of age - free access to concentrated feed. Feeding of animals was carried out according to the norms for this age of pigs. Clinical and physiological examinations of piglets were conducted prior to the search. They took into account their general state and activity when eating feed. On the $28^{\text {th }}$ day of life, piglets were weaned from the sow and regrouped from different nests for further retention and rearing, with changing dietary structure, which served as technological stress for the animal organism. Beginning at the age of 5 days, piglets of all groups were fed pre-stern compound feed. The piglets of the experimental 
group, from 21 to 40 days of age, were additionally fed the feed additive "Butaselmevit-plus" at a dose of $100 \mathrm{mg} / \mathrm{kg}$ of body weight per day.

The research material was blood collected in the morning prior to animals feeding by puncture of the cranial vena cava on $20^{\text {th }}$ day of life (period before weaning), on $25^{\text {th }}$ day of life (period before weaning), for 30 days of life ( $2^{\text {nd }}$ day after weaning), on $35^{\text {th }}$ day of life ( 7 days after weaning), on $40^{\text {th }}$ day of life ( $2^{\text {nd }}$ day after weaning).

In heparin-stabilized blood samples of piglets were determined: erythrocyte content, leukocyte count [11], hemoglobin concentration by hemoglobin-cyanide method, erythrocyte indexing using formulas. Protein-sensitizing liver function was determined by serum levels of total protein (biuret reaction) and protein fractions (by polyacrylamide gel electrophoresis).

\section{Results and discussion}

In pigs during the experiment, the number of erythrocytes in the blood of the control group of animals ranged from $5.65 \pm 0.06$ to $5.78 \pm 0.08 \mathrm{~T} / 1$. In terms of feeding of "Butaselmevit-plus" feed additive in the blood of pigs of the experimental group, the number of erythrocytes increased slightly compared to the control group. Thus, on the $35^{\text {th }}$ day of life in piglets of the experimental group, the number of erythrocytes increased by $4.6 \%$, while on the $40^{\text {th }}$ day of life - by $7.6 \%$, respectively (table 1).

Table 1

The number of erythrocytes in the blood of piglets under the action of the feed additive "Butaselmevit-plus", T/l (M $\pm \mathbf{m}, \mathbf{n}=5)$

\begin{tabular}{|l|c|c|}
\hline \multirow{2}{*}{$\begin{array}{c}\text { The day } \\
\text { of life }\end{array}$} & \multicolumn{2}{|c|}{ Groups of piglets } \\
\cline { 2 - 3 } & control & experimental \\
\hline $20^{\text {th }}$ & $5.65 \pm 0.06$ & $5.70 \pm 0.05$ \\
\hline $25^{\text {th }}$ & $5.74 \pm 0.07$ & $5.79 \pm 0.09$ \\
\hline $30^{\text {th }}$ & $5.70 \pm 0.05$ & $5.89 \pm 0.06^{*}$ \\
\hline $35^{\text {th }}$ & $5.78 \pm 0.08$ & $6.05 \pm 0.04^{*} *$ \\
\hline $40^{\text {th }}$ & $5.69 \pm 0.07$ & $6.12 \pm 0.09^{*} *$ \\
\hline
\end{tabular}

Note: in this and the following tables the degree of probability: * $-\mathrm{P}<0.05$; ** $-\mathrm{P}<0.025$; *** $-\mathrm{P}<0.001$.

In the search of the concentration of hemoglobin in the blood of the control group of piglets was found out, that this indicator increased slightly throughout the experience. It reached its maximum value on the $35^{\text {th }}$ day of life of piglets, where it was $84.67 \pm 1.19 \mathrm{~g} / \mathrm{l}$.

According to the research results, the use of the feed additive "Butaselmevit-plus" to piglets of the experimental group contributed to the probable increase in the level of hemoglobin in their blood from the $30^{\text {th }}$ day of life. After piglets weaning of this group, the hemoglobin level for the $30^{\text {th }}$ day of life in the blood of piglets of the experimental group was higher by $7.9 \%$. At the $35^{\text {th }}$ day of life, the hemoglobin level in the blood of the piglets of the experimental group increased by $10.1 \%$ compared with the control group. The highest hemoglobin level in the blood of piglets of the experimental group was at the $40^{\text {th }}$ day of life, where, respectively, it was $94.12 \pm 0.85 \mathrm{~g} / \mathrm{l}$, whereas in the control group of animals this indicator was $84.45 \pm 1.41 \mathrm{~g} / 1$ (table 2).

Table 2

The level of hemoglobin in the blood of piglets under the action of the feed additive "Butaselmevit-plus", g/l (M $\pm \mathbf{m}, \mathbf{n}=5)$

\begin{tabular}{|l|c|c|}
\hline \multirow{2}{*}{$\begin{array}{c}\text { The day } \\
\text { of life }\end{array}$} & \multicolumn{2}{|c|}{ Groups of piglets } \\
\cline { 2 - 3 } & control & experimental \\
\hline $20^{\text {th }}$ & $83.54 \pm 0.95$ & $84.10 \pm 0.97$ \\
\hline $25^{\text {th }}$ & $83.68 \pm 1.23$ & $83.90 \pm 1.04$ \\
\hline $30^{\text {th }}$ & $83.79 \pm 1.32$ & $90.41 \pm 0.90^{*}$ \\
\hline $35^{\text {th }}$ & $84.67 \pm 1.19$ & $93.25 \pm 1.05^{* * *}$ \\
\hline $40^{\text {th }}$ & $84.45 \pm 1.41$ & $94.12 \pm 0.85^{* * *}$ \\
\hline
\end{tabular}

It is important to determine the average hemoglobin content per erythrocyte, since this indicator indicates erythrocyte saturation with hemoglobin. It was found that in the control and experimental groups of the piglets the average hemoglobin content in one erythrocyte on the $20^{\text {th }}$ day of life was $14.79 \pm 0.41$ and $14.75 \pm 0.45 \mathrm{PG}$. After weaning of piglets, the average hemoglobin content of one erythrocyte on the $30^{\text {th }}$ day of the experiment was higher in the experimental group of piglets, where it increased by $4.4 \%$ compared to the control. In the future, the studied indicator was increased in the experimental group of piglets, where, respectively, it was $15.41 \pm 0.40 \mathrm{PG}$, whereas the control group of piglets was significantly lower and accordingly was $14.65 \pm 0.48 \mathrm{PG}$. On the $40^{\text {th }}$ day of life in piglets of the experimental group, the average hemoglobin content in one erythrocyte remained high, where compared to the control group of piglets it increased by $3.6 \%$ (table 3 ). 
Table 3

The average hemoglobin content in one erythrocyte in the blood of piglets under the action of feed additive "Butaselmevit-plus", PG $(M \pm m, n=5)$

\begin{tabular}{|l|c|c|}
\hline \multirow{2}{*}{$\begin{array}{c}\text { The day } \\
\text { of life }\end{array}$} & \multicolumn{2}{|c|}{ Groups of piglets } \\
\cline { 2 - 3 } & control & experimental \\
\hline $20^{\text {th }}$ & $14.79 \pm 0.41$ & $14.75 \pm 0.45$ \\
\hline $25^{\text {th }}$ & $14.58 \pm 0.45$ & $14.49 \pm 0.30$ \\
\hline $30^{\text {th }}$ & $14.70 \pm 0.43$ & $15.35 \pm 0.35$ \\
\hline $35^{\text {th }}$ & $14.65 \pm 0.48$ & $15.41 \pm 0.40$ \\
\hline $40^{\text {th }}$ & $14.84 \pm 0.50$ & $15.37 \pm 0.42$ \\
\hline
\end{tabular}

The change in leukocyte counts in the blood of piglets during the suckling period was characterized by a gradual increase in their number. Thus, in the control and experimental groups of piglets this figure for the $20^{\text {th }}$ day of life was $8.51 \pm 0.11$ and $8.45 \pm 0.15 \mathrm{G} / \mathrm{l}$, whereas for the $25^{\text {th }}$ day of life this indicator was increased by 2.1 and $3.2 \%$ compared to the indicators taken on the $20^{\text {th }}$ day of life of piglets (table 4 ).

The number of leukocytes in the blood of piglets under the action of the feed additive “Butaselmevit-plus", G/l (M $\pm \mathbf{m}, \mathbf{n = 5})$

\begin{tabular}{|l|c|c|}
\hline \multirow{2}{*}{$\begin{array}{c}\text { The day } \\
\text { of life }\end{array}$} & \multicolumn{2}{|c|}{ Groups of piglets } \\
\cline { 2 - 3 } & control & experimental \\
\hline $20^{\text {th }}$ & $8.51 \pm 0.11$ & $8.45 \pm 0.15$ \\
\hline $25^{\text {th }}$ & $8.69 \pm 0.07$ & $8.72 \pm 0.10$ \\
\hline $30^{\text {th }}$ & $7.98 \pm 0.10$ & $8.61 \pm 0.15^{* *}$ \\
\hline $35^{\text {th }}$ & $12.21 \pm 0.11$ & $11.60 \pm 0.20^{*}$ \\
\hline $40^{\text {th }}$ & $12.53 \pm 0.09$ & $10.18 \pm 0.14^{* * *}$ \\
\hline
\end{tabular}

After weaning of piglets, the blood of the control group of animals was observed a decrease in the number of leukocytes to $7.98 \pm 0.10 \mathrm{G} / 1$, however, was later noted an increase of this indicator by $53 \%$ compared to the previous day of the search. Feeding with "Butaselmevit-plus" feed supplement contributed to the increase number of leukocytes in the blood of piglets of the experimental group on the $30^{\text {th }}$ day of the experiment by $7.9 \%$. In 35 -days-old piglets from the experimental group, the number of leukocytes was decreased by $5 \%$ relative to the control group of piglets. At the $40^{\text {th }}$ day of life, the number of leukocytes in the blood of piglets of the experimental group ranged from $10.18 \pm 0.14 \mathrm{G} / 1$, whereas in the blood of piglets from the control group, this indicator was slightly lower and accordingly was $12.53 \pm 0.09 \mathrm{G} / 1$.
Therefore, weaning of piglets from sows at 28 days of age leads to a decrease in the number of leukocytes by the $30^{\text {th }}$ day of life with a further increase by the $35^{\text {th }}$ and $40^{\text {th }}$ day of life. The use of the feed additive "Butaselmevit-plus" contributed to the probable increase of hemoglobin and erythrocytes level in the blood of weaned piglets of the experimental group on the $35^{\text {th }}$ and $40^{\text {th }}$ days of the experiment.

It is known that blood indices of piglets depend on many factors (physiological state, ration, productivity, etc.). We have investigated the basic indicators of blood, which reflect the state of metabolic processes in the organism of animals.

The results of the search showed that the content of total protein in the serum of 20 daily pigs of the control and experimental groups ranged from $52.84 \pm 1.20-52.75 \pm 1.22 \mathrm{~g} / \mathrm{l}$. On the $25^{\text {th }}$ day of the experiment, the level of total protein in the control and experimental group was increased by 14.6 and $15.8 \%$ compared to the previous day of the search. After weaning in the blood of the piglets of the control group, the level of total protein on the $30^{\text {th }}$ and $35^{\text {th }}$ day of life fluctuated within $58.31 \pm 1.75$ and $58.12 \pm 1.33 \mathrm{~g} / 1$. The level of total protein was slightly higher in the blood of the experimental group during the indicated search period, which was increased accordingly by $5.5 \%$ and $6.6 \%$, respectively, relative to the control group of animals (table 5).

Content of total protein in the serum of piglets under the action of the feed additive "Butaselmevit-plus", g/l (M \pm m, n=5)

\begin{tabular}{|l|c|c|}
\hline \multirow{2}{*}{$\begin{array}{c}\text { The day } \\
\text { of life }\end{array}$} & \multicolumn{2}{|c|}{ Groups of piglets } \\
\cline { 2 - 3 } & control & experimental \\
\hline $20^{\text {th }}$ & $52.84 \pm 1.20$ & $52.75 \pm 1.22$ \\
\hline $25^{\text {th }}$ & $60.58 \pm 1.17$ & $61.08 \pm 0.87$ \\
\hline $30^{\text {th }}$ & $58.31 \pm 1.75$ & $61.54 \pm 1.10$ \\
\hline $35^{\text {th }}$ & $58.12 \pm 1.33$ & $61.78 \pm 0.91^{*}$ \\
\hline $40^{\text {th }}$ & $59.03 \pm 1.14$ & $61.24 \pm 0.95$ \\
\hline
\end{tabular}

In the blood of piglets of the control and experimental group after weaning on the $30^{\text {th }}, 35^{\text {th }}$ and $40^{\text {th }}$ days of the experiment, a higher content of albumin and a lower content of globulins were fixed (tables 6 and 7). Thus, on the $30^{\text {th }}$ day of piglets life the level of albumin in the blood of the control group was increased by $5.55 \%$ and in the experimental group - by $4.86 \%$ relative to 
The level of albumin in the serum of piglets under the action of the feed additive "Butaselmevit-plus", \% $(M \pm m, n=5)$

\begin{tabular}{|l|c|c|}
\hline \multirow{2}{*}{$\begin{array}{c}\text { The day } \\
\text { of life }\end{array}$} & \multicolumn{2}{|c|}{ Groups of piglets } \\
\cline { 2 - 3 } $20^{\text {th }}$ & control & experimental \\
\hline $25^{\text {th }}$ & $33.62 \pm 0.97$ & $33.65 \pm 1.05$ \\
\hline $30^{\text {th }}$ & $33.69 \pm 1.00$ & $33.70 \pm 1.10$ \\
\hline $35^{\text {th }}$ & $39.24 \pm 1.85$ & $38.56 \pm 1.12$ \\
\hline $40^{\text {th }}$ & $38.39 \pm 1.56$ & $39.52 \pm 1.85$ \\
\hline
\end{tabular}

The level of globulins in the serum of piglets under the action of the feed additive "Butaselmevit-plus", \% (M $\pm m, n=5)$

\begin{tabular}{|l|c|c|}
\hline \multirow{2}{*}{$\begin{array}{c}\text { The day } \\
\text { of life }\end{array}$} & \multicolumn{2}{|c|}{ Groups of piglets } \\
\cline { 2 - 3 } & control & experimental \\
\hline $20^{\text {th }}$ & $66.38 \pm 0.97$ & $66.35 \pm 1.05$ \\
\hline $25^{\text {th }}$ & $66.31 \pm 1.00$ & $66.30 \pm 1.10$ \\
\hline $30^{\text {th }}$ & $60.76 \pm 1.85$ & $61.44 \pm 1.12$ \\
\hline $35^{\text {th }}$ & $61.61 \pm 1.56$ & $60.48 \pm 1.85$ \\
\hline $40^{\text {th }}$ & $57.36 \pm 1.97$ & $64.13 \pm 1.10^{* *}$ \\
\hline
\end{tabular}

the indicators taken from the 25 daily pigs. In the 35-day-old piglets of the experimental group had an albumin level of $1.13 \%$ higher than the control group. On the $40^{\text {th }}$ day of the experiment, the level of albumin was the highest in the blood of the piglets of the control group.

The level of globulins in the blood of 25 daily pigs of the control and experimental groups ranged from $66.31 \pm 1.00$ and $66.30 \pm 1.10 \%$. After weaning in the piglets from the experimental groups, the level of globulins was decreased on the $30^{\text {th }}$ day of life, so in the blood of piglets from the control group the level of globulins was decreased by $5.55 \%$, and in the experimental group - by $4.86 \%$ relative to the indicators taken on the $25^{\text {th }}$ day of the experiment.

So feeding piglets with feed additives "Butaselmevit-plus" promotes the enhancement of protein synthesis of the liver.

\section{Conclusions}

Weaning of piglets from sows at 28 days of age leads to a decrease in the number of leukocytes on the $30^{\text {th }}$ day of life with a further increase on the $35^{\text {th }}$ and $40^{\text {th }}$ day of life. The use of the feed additive "Butaselmevit-plus" contribut- ed to the probable increase of hemoglobin and erythrocytes in the blood of weaned piglets of the experimental group on the $35^{\text {th }}$ and $40^{\text {th }}$ days of the experiment.

Piglets feeding with feed additives " $\mathrm{Bu}$ taselmevit-plus" promotes the enhancement of protein synthesizing function of the liver. The increase in total protein content in the serum of piglets of the experimental group during the indicated periods of the experiment, compared with the control, indicates the stimulating influence of vitamins $A, D_{3}, E$ and milk thistle spotted in the composition of feed additives for protein synthesis. Also in the blood of piglets of the control and experimental group after weaning on the 30, 35 and 40 days of the experiment was fixed a higher content of albumin and a lower content of globulins.

Perspectives of future investigations. In the future, it is planned to conduct research on the effect of feed additive "Butaselmevit-plus" on the state of antioxidant protection of piglets during weaning, namely on the indicators of the enzyme and non-enzymatic units of the glutathione system.

1. Blecha F., Kelley K.W. Effects of cold stress and weaning stressors on the antibody-mediated immune response of pigs. J Anim Sci, 1981, vol. 53, pp. 439-447. DOI: 10.2527/jas 1981.532439x.

2. Chemiy N. V., Matsenko E. V., Shchepetilnikov Yu.A., Maslak Yu. V., Machula O. S., Furda I. V., Voronyak V. V., Gutyj B. V. Influence of the supplement "Press-Acid" on proteinmineral metabolism and resistance of piglets. Scientific Messenger of Lviv National University of Veterinary Medicine and Biotechnologies. Series: Veterinary Sciences, 2018, vol. 20, issue 83, pp. 320-324. DOI: 10.15421/ nvlvet 8364 .

3. Coalson J. A., Lecce J. G. Influence of nursing intervals on changes in serum protein (immunoglobulins) in neonatal pigs. Journal of Animal Science, 1973, vol. 36, issue 2, pp. 381-385. DOI: $10.2527 /$ jas 1973.362381x.

4. Gutyj B., Leskiv K., Shcherbatyy A., Pritsak V., Fedorovych V., Fedorovych O., Rusyn V., Kolomiiets I. The influence of Metisevit on biochemical and morphological indicators of blood of piglets under nitrate loading. Regulatory Mechanisms in Biosystems, 2017, vol. 8, issue 3, pp. 427-432. DOI: $10.15421 / 021766$.

5. Iesina E. V., Tishkina N. M., Gutyj B. V. Pathoanatomical diagnosis, treatment and preventive 
measures at pigs gastroenterocolitis. Scientific Messenger of Lviv National University of Veterinary Medicine and Biotechnologies. Series: Veterinary Sciences, 2018, vol. 20, issue 83, pp. 429-434. DOI: $10.15421 /$ nvlvet8384.

6. Khalak V. I., Gutyj B. V., Stadnitska O. I. Feeding and meat qualities of young pigs of different origin and intensity of formation in early ontogenesis. Scientific Messenger of Lviv National University of Veterinary Medicine and Biotechnologies. Series: Agricultural sciences, 2019, vol. 21, issue 91, pp. 10-15. DOI: $10.32718 /$ nvlvet-a9102.

7. Martyshuk T., Gutyj B. Influence of feed additive "Butaselmevit-Plus" on antioxidant status of rats in conditions of oxidative stress. Scientific Messenger of LNU of Veterinary Medicine and Biotechnologies. Series: Agricultural Sciences, 2019, vol. 21, issue 90, pp. 76-81. DOI: 10.32718/nvlvet-a9013.

8. Martyshuk T. V., Gutyj B. V., Vishchur O. I. Indicators of functional and antioxidant liver status of rats under oxidative stress conditions and on the action of the liposomal drug "Butaselmevit". Scientific Messenger of LNU of Veterinary Medicine and Biotechnologies. Series: Agricultural Sciences, 2018, vol. 20, issue 89, pp. 100-107. DOI: $10.32718 /$ nvlvet8919.

9. Stetsiv I. C., Stetsiv I. I. Quality control system for meat processing enterprises in Ukraine: problems and ways of their solution. Scientific Messenger of LNU of Veterinary Medicine and Biotechnologies. Series: Agricultural Sciences, 2019, vol. 21, issue 90, pp. 113-120. DOI: 10.32718/ nvlvet-a9020.

10.Zhukova I. O., Molchanov A. A., Antipin S. L. Increase in resistance of pigs to oxidative stress by means of plant origin. Scientific Messenger of LNU of Veterinary Medicine and Biotechnologies. Series: Agricultural Sciences, 2017, vol. 19, issue 74, pp. 33-37. DOI: 10.15421/nvlvet7408.

11. Vlizlo V. V. (ed.), Fedoruk R. S., Ratych I. B. Laboratory methods of investigation in biology, stock-breeding and veterinary. A reference book. Lviv, 2012, 764 p. (in Ukrainian) 